\title{
EFFECT OF CALPASTATIN GENE POLYMORPHISM ON LAMB GROWTH AND MUSCLING
}

\author{
Monika Greguła-Kania \\ Department of Small Ruminant Breeding and Agriculture Advisory Service, \\ University of Life Sciences in Lublin, Akademicka 13, 20-950 Lublin, Poland
}

\begin{abstract}
The calpain-calpastatin system plays a key role in skeletal muscle growth and development processes. It is known that calpastatin activity correlates highly with muscle growth rate, which implies that skeletal muscle growth is likely to result from reduced protein degradation due to compromised activity of calpains or substantial increase of calpastatin activity. The objective of the present research was to identify polymorphic forms in intron 12 of the ovine calpastatin gene in sheep of synthetic lines BCP and SCP, followed by determination of the correlation between each polymorphic form of $C A S T$ gene and chosen traits characterizing lamb growth and muscling. The present study's results suggest that lambs carrying the "b" and "e" alleles and the "ae" genotype could be preferred when selecting for growth rate. The breeding efforts to obtain substantial increases in sheep muscle mass could focus on animals carrying the "ac" genotype. No statistically significant relationship was observed in any of the analysed cases between values of the traits and the CAST genotype. However, a highly significant effect of the study year on the analysed traits was found. The results should be regarded as preliminary. The research should be continued on a larger group of animals to ensure the adequate number of each genotype. The trends mentioned and discussed above may also serve as an indicator showing the future direction of further studies in this area.
\end{abstract}

Key words: sheep, calpastatin polymorphism gene, muscle growth

Carcass and meat quality are quantitative traits attributed to polygenic effects and environmental conditions. The traditional methods applied to improve them turned out to be inefficient and low heritability has remained the main drawback. The rapid development of molecular genetics facilitated the recognition of localization, structure and operation of genes that may have a large effect on specific traits. One of the ways of identifying genes that determine a given trait group is to evaluate DNA polymorphism in a candidate gene underlying the trait and contributing to a phenotype. These gene products participate in the physiological processes leading to trait expression, while polymorphic forms of the gene are associated with trait variation. 
The calpain-calpastatin system plays a key role in skeletal muscle growth and development processes (Goll et al., 2003). It is known that calpastatin activity correlates highly with muscle growth rate, which implies that skeletal muscle growth is likely to result from reduced protein degradation due to compromised activity of calpains or substantial increase of calpastatin activity.

The gene encoding calpastatin (CAST) is considered a marker associated with assessment of body weight growth and tissue composition of carcass as well as quality traits of swine and cattle meat (Casas et al., 2006; Schenkel et al., 2006; KoćwinPodsiadła et al., 2003). In sheep, the problem has been addressed in only a few research papers so far and therefore, taking into account vital economic aspects, a relationship between quantitative traits characterizing ovine meat quality and CAST polymorphism should be established. The objective of the present research was to identify polymorphic forms in intron 12 of the ovine calpastatin gene in sheep of synthetic lines BCP and SCP, followed by determination of the correlation between each polymorphic form of CAST gene and chosen traits characterizing lamb growth and muscling.

\section{Material and methods}

The research material involved lamb rams of synthetic prolific-meat lines BCP and SCP born in 2007 and 2008 at the Small Ruminant Experimental Station in Bezek, a part of The University of Life Sciences in Lublin. The animals of both lines are characterized by a high level of reproduction performance with concomitant high parameters of meat performance (Gruszecki and Lipecka, 2002).

The lambs were reared with mothers until 70 days of age, after which they were weaned and fed a complete diet until 120 days of age. The lambs were then transported for slaughter to the "Połonina" Slaughterhouse in Lesko. The performed DNA analysis was based on peripheral blood samples taken from the lambs under fattening and slaughter evaluation.

The blood samples were collected from the jugular vein to disposable syringes (Monovette, Sarstedt) with EDTA as coagulant. DNA was isolated from blood using the commercial kit reagents (Blood Mini, A\&A Biotechnology) according to the procedure recommended by the manufacturer. Quantitative and qualitative determination of isolated DNA was performed by the spectrophotometric method.

Amplification of the appropriate fragment of CAST gene was performed with primers complementary to the flanking regions of the target fragment of intron 12 of the CAST gene according to Palmer et al. (2000). The PCR process was carried out in a PTC-220 DNA Engine thermocycler (MJ Research). Each sample contained $10 \mu \mathrm{l}$ of RADTaq ReadyMix (Sigma), $0.2 \mu 1$ of each primer (15 pmol; Operon), genomic DNA $(2 \mu \mathrm{l})$ and water deionized to $20 \mu \mathrm{l}$ volume. The following conditions of the PCR reaction were applied: $95^{\circ} \mathrm{C}$ for $2 \mathrm{~min}, 95^{\circ} \mathrm{C}$ for $60 \mathrm{~s}, 62^{\circ} \mathrm{C}$ for $60 \mathrm{~s}, 72^{\circ} \mathrm{C}$ for $120 \mathrm{~s}$, and final extension at $72^{\circ} \mathrm{C}$ for $10 \mathrm{~min}$. The PCR procedure comprised $35 \mathrm{suc}-$ cessive thermal cycles. Each sample underwent three separate reactions of restrictase 
digestion according to Palmer (2000). The PCR product was digested with 6U of each of the following enzymes: MspI, NcoI, Hin6I (Fermentas). The PCR-RFLP test was conducted at $37^{\circ} \mathrm{C}$ for 4 hours and the results were observed during electrophoresis using SubCell GT system (Bio-Rad) in 2\% agarose gel (Prona Agarose) with ethidium bromide addition. A DNA molecular weight marker with size range of 50-1000 bp (Gene Ruler 50bp DNA Ladder, Fermentas) was used, with gel documentation system provided by Vilber Lourmat ECX-20M apparatus.

CAST polymorphism was studied in 164 rams and, as a result, 4 alleles (a, b, c, e) and 8 genotypes (aa, ab, ac, ae, bb, cc, ce, ee) were identified (Greguła-Kania, 2011). The next research stages included 149 lambs carrying "aa", "ac" and "ae" genotypes, because the subclasses with the numbers below 8 were left out. The numbers of animals under the growth and muscling analyses are presented in tables.

Lamb body weight was checked at birth and at 28, 56, 70 and 120 days of age to calculate daily weight gains. The cross-sectional area of m. longissimus lumborum behind the last thoracic vertebra was monitored twice (80 and 120 days of age) using ultrasound technique when the muscle depth and the overlying fat thickness were established. Lambs were examined with ultrasonography (Aloka SSD 210 DX equipped with a $5 \mathrm{MHz}$ linear probe).

The results characterizing the investigated parameters of fattening and slaughter performance were analysed statistically by variance analysis according to Harvey's Least square program (LSMLMW) using the following model:

$$
Y i j k=u+a i+b j+c k+a b i j+a c j k+e i j k
$$

where:

Yijk - level of studied trait,

$\mathrm{u}-$ arithmetic mean for population,

ai - effect of CAST genotype $(i=1 \ldots 3)$ /effect of CAST allele $(i=1 \ldots 4)$,

$\mathrm{bj}$ - effect of lambing year $(\mathrm{j}=1,2)$,

$\mathrm{ck}$ - effect of synthetic line $(\mathrm{k}=1,2)$,

abij - effect of genotype/allele $\times$ lambing year interaction,

acik - effect of genotype/allele $\times$ synthetic line interaction,

eijk - error.

Each trait was analysed twice in the allele and genotype arrangement.

\section{Results}

Analysis of body weight growth of animals carrying given alleles (Table 1) showed that the highest value of the studied trait at birth was established in the animals with identified "a" and "e" alleles. At the completion of lamb fattening (120 days of age), animals weighed from 31.14 to $33.83 \mathrm{~kg}$, with the peak value recorded in animals with "b" allele in genotype. No statistical differences were observed for 
any analysed case and life period. However, there was a significant $(\mathrm{P}<0.01)$ effect of study year and year $\times$ line interaction on the analysed trait value in most periods of life.

Table 1. Body weight $(\mathrm{kg})$ of ram lambs of synthetic lines BCP and SCP with different alleles at the CAST locus

\begin{tabular}{|c|c|c|c|c|c|c|c|c|c|c|c|c|}
\hline \multirow{3}{*}{ Item } & \multicolumn{8}{|c|}{ CAST allele } & \multicolumn{3}{|c|}{ Effect of factors } & \multirow{3}{*}{ Interaction } \\
\hline & \multicolumn{2}{|c|}{$\begin{array}{c}\mathrm{a} \\
\mathrm{n}=231\end{array}$} & \multicolumn{2}{|c|}{$\begin{array}{c}\mathrm{b} \\
\mathrm{n}=10\end{array}$} & \multicolumn{2}{|c|}{$\begin{array}{c}\mathrm{c} \\
\mathrm{n}=33\end{array}$} & \multicolumn{2}{|c|}{$\begin{array}{c}\mathrm{e} \\
\mathrm{n}=54\end{array}$} & \multirow{2}{*}{$\begin{array}{c}\text { year } \\
(\mathrm{Y})\end{array}$} & \multirow{2}{*}{$\begin{array}{l}\text { line } \\
(\mathrm{L})\end{array}$} & \multirow{2}{*}{$\begin{array}{c}C A S T \\
\text { allele } \\
\text { (A) }\end{array}$} & \\
\hline & LSM & $\mathrm{SD}$ & LSM & $\mathrm{SD}$ & LSM & SD & LSM & $\mathrm{SD}$ & & & & \\
\hline Birth & 4.72 & 0.06 & 3.9 & 0.28 & 4.26 & 0.16 & 4.72 & 0.12 & & $*$ & & \\
\hline Day 28 & 11.27 & 0.15 & 11.35 & 0.47 & 10.59 & 0.50 & 11.26 & 0.30 & & & & \\
\hline Day 56 & 20.17 & 0.27 & 19.67 & 1.19 & 19.27 & 0.68 & 20.39 & 0.58 & $* *$ & & & $\mathrm{Y} \times \mathrm{L} * *$ \\
\hline Day 70 & 25.54 & 0.35 & 28.09 & 2.13 & 24.66 & 0.80 & 26.12 & 0.80 & $* *$ & & & $\mathrm{Y} \times \mathrm{L}^{* *}$ \\
\hline Slaughter & 31.27 & 0.32 & 33.83 & 1.48 & 31.58 & 0.84 & 31.14 & 0.70 & $* *$ & & & $\mathrm{Y} \times \mathrm{L} * *$ \\
\hline
\end{tabular}

$*-\mathrm{P} \leq 0.05$. ** $-\mathrm{P} \leq 0.01$.

Table 2. Body weight $(\mathrm{kg})$ of ram lambs of synthetic lines BCP and SCP with different genotypes at the $C A S T$ locus

\begin{tabular}{|c|c|c|c|c|c|c|c|c|c|c|}
\hline \multirow{3}{*}{ Item } & \multicolumn{6}{|c|}{$C A S T$ genotype } & \multicolumn{3}{|c|}{ Effect of factors } & \multirow{3}{*}{ Interaction } \\
\hline & \multicolumn{2}{|c|}{$\begin{array}{c}\text { aa } \\
\mathrm{n}=74\end{array}$} & \multicolumn{2}{|c|}{$\begin{array}{c}\mathrm{ac} \\
\mathrm{n}=26\end{array}$} & \multicolumn{2}{|c|}{$\begin{array}{c}\text { ae } \\
\mathrm{n}=49\end{array}$} & \multirow{2}{*}{$\begin{array}{l}\text { year } \\
(Y)\end{array}$} & \multirow{2}{*}{$\begin{array}{l}\text { line } \\
\text { (L) }\end{array}$} & \multirow{2}{*}{$\begin{array}{c}C A S T \\
\text { genotype } \\
(\mathrm{G})\end{array}$} & \\
\hline & LSM & SD & LSM & LSM & SD & LSM & & & & \\
\hline Birth & 4.77 & 0.12 & 4.32 & 0.19 & 4.78 & 0.12 & & & & \\
\hline Day 28 & 11.31 & 0.26 & 10.88 & 0.52 & 11.39 & 0.31 & & & & \\
\hline Day 56 & 20.21 & 0.47 & 19.47 & 0.80 & 20.54 & 0.62 & $* *$ & & & \\
\hline Day 70 & 25.42 & 0.56 & 24.86 & 0.94 & 26.30 & 0.86 & $* *$ & & & \\
\hline Slaughter & 31.43 & 0.55 & 31.85 & 0.98 & 31.13 & 0.76 & & & & $\mathrm{Y} \times \mathrm{G}^{*}$ \\
\hline
\end{tabular}

${ }^{*}-\mathrm{P} \leq 0.05$. ** $-\mathrm{P} \leq 0.01$.

Comparison of animals with different genotypes (Table 2) showed similar birth weight of the "aa" and "ae" individuals (4.78 and $4.77 \mathrm{~kg}$, respectively) and slightly lower birth weight in the "ac" animals $(4.32 \mathrm{~kg})$. This tendency remained evident until 70 days of age, whereas at slaughter all the animals weighed between 31 and $32 \mathrm{~kg}$. Like for the previous comparison, the differences were statistically non-significant. However, there was a highly significant effect of the study year on body weight at 56 and 70 days of age as well as a statistically significant year $\times$ CAST genotype interaction. 


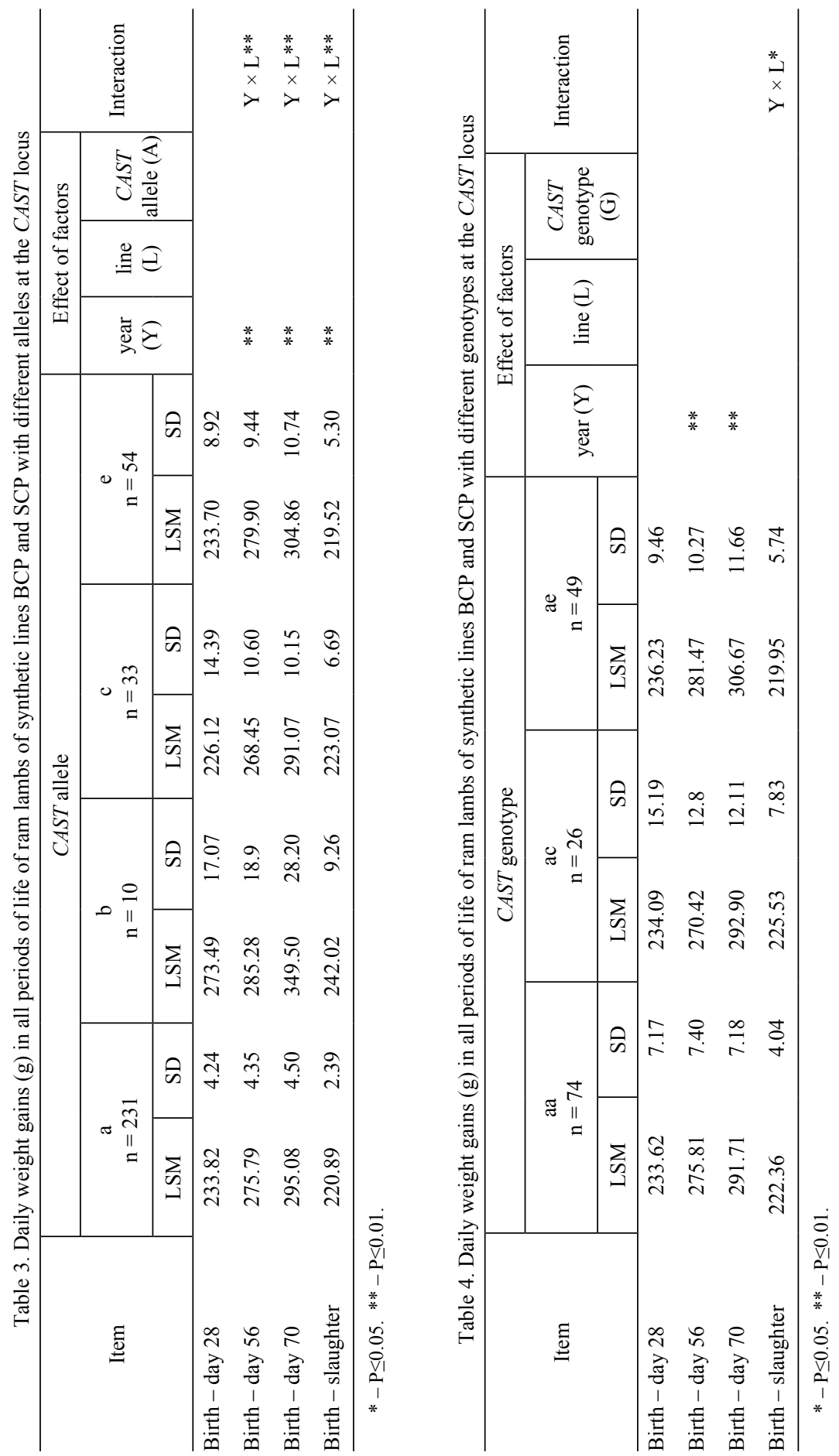


The results characterizing the lamb body weight served to calculate daily weight gains (Tables 3 and 4). The assessment of this trait showed a highly significant effect of the study year in the alleles and genotype arrangement and the research year $x$ line interaction in the allele system. Comparison of the animals carrying different alleles (Table 3 ) showed that the animals with " $b$ " alleles had the highest ( $242 \mathrm{~g}$ ) daily weight gains in all periods of life. The differences regarding the peers with the other alleles ranged from $10 \%$ to $17 \%$, but without statistical confirmation. Evaluation of daily weight gains in relation to genotype indicated that "ae" animals had higher values of the trait as compared to the peers (Table 4) and this tendency persisted from birth until 70 days of age. Daily weight gains were calculated for the entire life span (birth to slaughter) and were similar in each group, averaging $220 \mathrm{~g} / \mathrm{day}$.

Table 5. Muscle depth ( $\mathrm{mm})$ and thickness of fat tissue over $m$. longissimus at 80 and 120 days of age of ram lambs of synthetic lines BCP and SCP with different alleles at the CAST locus

\begin{tabular}{|c|c|c|c|c|c|c|c|c|c|c|c|}
\hline & \multirow{3}{*}{ Item } & \multicolumn{6}{|c|}{ CAST allele } & \multicolumn{3}{|c|}{ Effect of factors } & \multirow{3}{*}{$\begin{array}{l}\text { Inter- } \\
\text { action }\end{array}$} \\
\hline & & \multicolumn{2}{|c|}{$\begin{array}{c}\mathrm{a} \\
\mathrm{n}=130\end{array}$} & \multicolumn{2}{|c|}{$\begin{array}{c}c \\
n=13\end{array}$} & \multicolumn{2}{|c|}{$\begin{array}{c}\mathrm{e} \\
\mathrm{n}=28\end{array}$} & \multirow{2}{*}{$\begin{array}{c}\text { year } \\
(Y)\end{array}$} & \multirow{2}{*}{$\begin{array}{l}\text { line } \\
\text { (L) }\end{array}$} & \multirow{2}{*}{$\begin{array}{c}C A S T \\
\text { allele } \\
\text { (A) }\end{array}$} & \\
\hline & & LSM & SD & LSM & $\mathrm{SD}$ & LSM & $\mathrm{SD}$ & & & & \\
\hline \multirow{2}{*}{$\begin{array}{l}\text { Day } 80 \\
\text { of age }\end{array}$} & muscle depth & 23.64 & 0.31 & 25.57 & 0.84 & 23.49 & 0.61 & & & & \\
\hline & fat thickness & 2.47 & 0.08 & 2.64 & 0.25 & 2.61 & 0.18 & & & & \\
\hline \multirow{2}{*}{$\begin{array}{l}\text { Day } 120 \\
\text { of age }\end{array}$} & muscle depth & 26.39 & 0.3 & 28.2 & 0.42 & 26.4 & 0.7 & & & & \\
\hline & fat thickness & 3.2 & 0.09 & 3.47 & 0.29 & 3.28 & 0.15 & $* *$ & & & $\mathrm{Y} \times \mathrm{A}^{* *}$ \\
\hline
\end{tabular}

* $-\mathrm{P} \leq 0.05$. ** $-\mathrm{P} \leq 0.01$.

Table 6. Muscle depth (mm) and thickness of fat tissue over $m$. longissimus at 80 and 120 days of age of ram lambs of synthetic lines BCP and SCP with different genotypes at the CAST locus

\begin{tabular}{|c|c|c|c|c|c|c|c|c|c|c|c|}
\hline & \multirow{3}{*}{ Item } & \multicolumn{6}{|c|}{$C A S T$ genotype } & \multicolumn{3}{|c|}{ Effect of factors } & \multirow{3}{*}{$\begin{array}{l}\text { Inter- } \\
\text { action }\end{array}$} \\
\hline & & \multicolumn{2}{|c|}{$\begin{array}{c}\text { aa } \\
\mathrm{n}=44\end{array}$} & \multicolumn{2}{|c|}{$\begin{array}{c}\mathrm{ac} \\
\mathrm{n}=13\end{array}$} & \multicolumn{2}{|c|}{$\begin{array}{c}\mathrm{ae} \\
\mathrm{n}=24\end{array}$} & \multirow{2}{*}{$\begin{array}{l}\text { year } \\
(Y)\end{array}$} & \multirow{2}{*}{$\begin{array}{l}\text { line } \\
\text { (L) }\end{array}$} & \multirow{2}{*}{$\begin{array}{c}C A S T \\
\text { geno- } \\
\text { type } \\
\text { (G) }\end{array}$} & \\
\hline & & LSM & $\mathrm{SD}$ & LSM & $\mathrm{SD}$ & LSM & SD & & & & \\
\hline \multirow{2}{*}{$\begin{array}{l}\text { Day } 80 \\
\text { of age }\end{array}$} & muscle depth & 23.78 & 0.56 & 25.57 & 0.84 & 23.31 & 0.71 & & & & \\
\hline & fat thickness & 2.47 & 0.15 & 2.64 & 0.25 & 2.50 & 0.19 & & & & \\
\hline \multirow{2}{*}{$\begin{array}{l}\text { Day } 120 \\
\text { of age }\end{array}$} & muscle depth & 26.35 & 0.47 & 28.2 & 0.42 & 26.32 & 0.73 & & & & \\
\hline & fat thickness & 3.22 & 0.18 & 3.45 & 0.29 & 3.20 & 0.15 & $* *$ & $*$ & & $\mathrm{Y} \times \mathrm{G}^{*}$ \\
\hline
\end{tabular}

$*_{-} \mathrm{P} \leq 0.05$. ** $-\mathrm{P} \leq 0.01$.

The ultrasound images obtained on day 80 of lamb age revealed $23-25 \mathrm{~mm}$ depth of the longest muscle ( $m$. longissimus lumborum) and 2.4-2.6 mm fat layer thickness (Table 5). On day 120 of age, the values of the analysed traits increased naturally and still no significant influence of each allele at the $C A S T$ locus on their level was observed (Table 5). Analogical comparison of results for each CAST genotype (Table 6) did not show statistically significant differences related to the level of the analysed traits either. 


\section{Discussion}

The first trait under study was body weight, which is considered a measurable estimate of body growth and partly its development. The evidence-based literature reviews state explicitly that the calpain-calpastatin system contributes to the muscle growth and development process through the regulation of degradation and synthesis rate of new proteins. The present study has determined the impact of CAST genotypes on body weight in each period of animal's life (Tables 1 and 2). No statistically significant differences were established for body weight according to period of life of animals of different genotypes and different alleles in the genotype. In the systems under investigation, the most frequent proved to be the statistically significant effect of the study year and year $\times$ line interaction on animal body weight. These correlations can most probably be attributed to changeable environmental conditions recorded each year of the animal rearing period.

The studies conducted by other authors indicate higher correlations between body weight and actual CAST alleles or genotypes. In Romney sheep, Byun et al. (2008) found a significant effect of the A and C genotypes at the CAST locus (polymorphism detected in exon 6 of the gene encoding L domain of calpastatin protein) on birth weight. Whereas the investigations of other authors (Chung et al., $2001 \mathrm{a}, \mathrm{b}$ ) carried out with beef cattle breeds showed the effect of mutations in the region encoding domain I of protein on calf body weight at 56 days of age. The homozygous $\mathrm{BB}$ animals were characterized by significantly higher body weight compared to the $\mathrm{AA}$ and $\mathrm{AB}$ animals.

Our statistical analysis showed that in the case of the next trait discussed, the animals with the "b" allele had the highest daily weight gains throughout nearly all the life periods (Table 3). This result is a sequela of high body weight of these animals in each period of life and is the lowest at birth (Table 1). It should be noted, however, that "b" allele occurs in only 10 animals, suggesting that this allele is most likely eliminated from the population due to selection.

A study by Palmer et al. (1999) addressing the discussed problems indicates that growth rate is modified by inhibitory activity of calpastatin towards calpain depending on its genetic variant, i.e. CAST genotype. Like in our study, Dorset sheep with "ac" genotype in the intron 12 of the CAST gene demonstrated significantly higher daily live weight gains and carcasses heavier by $12-17 \%$ compared to the animals with "aa" and "ab" genotypes (Palmer et al., 1999). These authors, however, highlighted a significant impact of the year due to substantial weight differences at weaning and animals' daily weight gains recorded in successive years of the study. In Kurdish sheep, the "ab" genotype controlled significantly elevated weight gains during the birth to weaning period and between 9 and 12 months of age (Nassiry et al., 2006).

Unlike our study, the works of Palmer et al. (1999) and Nassiry et al. (2006) showed statistically significant differences in growth rate of animals from different groups. Importantly, these authors' research was performed with a relatively small number of animals as compared to our study. 
An overall detailed analysis of our findings illustrating the lamb growth rate (Tables 1 to 4), despite the lack of statistical confirmation, revealed certain patterns in this area. The lambs with "b" and "e" alleles and "ae" genotype predominated over the peers in respect of growth rate until 70 days of age. However, in the case of this analysis, allele " $b$ " was represented by too few individuals, which precludes definitive conclusions. The tendency mentioned above proves to be very interesting from the practical breeding standpoint, especially in the populations oriented towards lighter lamb production (up to $20-25 \mathrm{~kg}$ body weight).

Ultrasound modality was used to determine the longest dorsal muscle length and fat layer thickness over this muscle at 80 and 120 days of age. Research demonstrates (Silva et al., 2007) that these measurements appear to be most reliable when muscling and fatness are scored in a live animal. Although no statistically significant differences were determined in relation to the level of the studied trait between the animals with different $C A S T$ alleles and genotypes (Tables 5 and 6), a detailed analysis of the values obtained allows stating that animals with the "c" allele had the muscle tissue deeper by approximately $8-9 \%$ compared to the peers. This held true for comparison of both alleles and genotypes. A similar pattern also applies to the fat layer which was thicker by $\sim 6.5 \%$ in lamb rams with the "c" allele at the CAST locus. The tendencies determined and described above also make an interesting guideline that will help orient further studies in this field.

Research with pigs explored the effect of CAST genotype on loin eye area and, like in the present paper, the impact on fat thickness (Kurył et al., 2003). The individuals with DD genotype at locus CAST/MspI and EE genotype at locus CAST/RsaI turned out to have lower fat thickness and the largest loin eye area.

The research findings of numerous authors suggest that in the case of cattle and swine, the CAST gene may be a helpful tool in marker assisted selection (MAS) aimed to improve meat performance, among others. Whereas the results of the present study showed that lambs carrying the "b" and " $\mathrm{e}$ " alleles and the "ae" genotype should be preferred when selecting for growth rate. The breeding efforts to obtain substantial increases in sheep muscle mass should focus on the animals carrying the "ac" genotype. No statistically significant relationship was observed in any of the analysed cases between values of the traits and the CAST genotype. However, a highly significant effect of the study year on the analysed traits was found. The results should be regarded as preliminary. The research should be continued on a larger group of animals to ensure the adequate number of each genotype. The trends mentioned and discussed above may also serve as an indicator showing the future direction of further studies in this area.

\section{References}

B yun S.O., Zhou H., F orrest R.H., Frampton C.M., Hi ckford J.G. (2008). Association of the ovine calpastatin gene with birth weight and growth rate to weaning. Anim Genet., 39 (5): $572-573$. 
Cas a s E., White S.N., Whe eler T.L., Shackelford S.D., Ko o h marai e M., Rile D.G., Chale C.C., John s on D.D., S mith P.L. (2006). Effects of calpastatin and $\mu$-calpain markers in beef cattle on tenderness traits. J. Anim. Sci., 84: 520-525.

Chung H.Y., Davis M.E., Hines H.C. (2001 a). Effects of calpain and calpastatin genotypes on growth of Angus bulls. Ohio State University Extension Research Bulletin: Special Circular, pp. 181-201.

Chung H.Y., D a vis M.E., H in e s H.C. (2001 b). Genetic variants detected by PCR-RFLP in intron 6 of the bovine calpastatin gene. Anim. Genet., 32: 40-53.

Go 11 D.E., Thomps on V.F., Li H., W e W., Cong J. (2003). The calpain system. Physiol. Rev., 83: $731-801$.

Greguła-Kania M. (2011). New allelic variant of the ovine calpastatin gene. Afr. J. Biotechnol., 10 (61): 13082-13085.

Gruszecki T., Li pe cka C. (2002). Evaluation of the implementation of national programme for improvement of sheep prolificacy and plans for the future (in Polish). Anim. Prod. Rev., 6: 10-12.

Koćw in - P od s i a dła M., Kurył J., Krzęc i o E., Z y bert A., Przybylski W. (2003). The interaction between calpastatin and $R Y R 1$ genes for some pork quality traits. M. Sci., 65: 731-735.

Kurył J., Kapelański W., Pierzchała M., Grajewska S., B ocian M. (2003). Preliminary observations on the effect of calpastatin gene (CAST) polymorphism on carcass traits in pigs. Anim. Sci. Pap. Rep., 21, 2: 87-95.

Na s s iry M.R., T a h moure s P.M., J a vad M.A., S o lt a n i M., F o rou tan i F.S. (2006). Calpastatin polymorphism and its association with daily gain in Kurdi sheep. Iran. J. Biotechnol., 4 (3): $188-192$.

P a $1 \mathrm{~m}$ e r B.R., M o r t o n J.D., R o b e r t s N., I 1 i a n M.A. (1999). Marker-assisted selection for meat quality and the ovine calpastatin gene. Proc. New Zealand Soc. Anim. Prod., 59: 266-268.

P a $1 \mathrm{~m}$ e r B.R., S u H.Y., R ob er t s N., H i c k ford J.G., B i c kers t a f fe R. (2000). Single nucleotide polymorphisms in an intron of the ovine calpastatin gene. Anim. Biotechnol., 11 (1): 63-67.

Schenkel F.S., Miller S.P., Jiang Z., Mandell B.I., Ye X., Li H., Wilton W.J. (2006). Association of single nucleotide polymorphism in the calpastastin gene with carcass and meat quality traits of beef cattle. J. Anim. Sci., 84: 291-299.

Silva S.R., Guedes C.M., S antos V.A., L o u re n c o A.L., A z e vedo J.M.T., D i a s - d a - S i lv a A. (2007). Sheep carcass composition estimated from longissimus thoracis et lumborum muscle volume measured by in vivo real-time ultrasonography. M. Sci., 76: 708-714.

Accepted for printing 21 XI 2011

\section{MONIKA GREGUŁA-KANIA}

\section{Wpływ polimorfizmu genu kalpastatyny na wzrost i umięśnienie jagniąt}

\section{STRESZCZENIE}

System kalpaina-kalpastatyna odgrywa znaczącą rolę w procesach wzrostu i rozwoju mięśni szkieletowych. Wiadomo, że aktywność kalpastatyny pozostaje w wysokiej korelacji z tempem wzrostu mięśnia, co sugeruje, że wzrost mięśni szkieletowych może być wynikiem zmniejszonej degradacji białek na skutek zmniejszonej aktywności kalpain lub znacznego wzrostu aktywności kalpastatyn. Celem badań była identyfikacja polimorficznych form w 12 intronie genu kalpastatyny u owiec linii syntetycznych BCP i SCP, a następnie określenie współzależności pomiędzy poszczególnymi formami polimorficznymi genu CAST a wybranymi cechami charakteryzującymi wzrost i umięśnienie jagniąt. Wyniki badań własnych sugerują, że jagnięta z allelami „,b” i „e” oraz genotypem ,aae” mogły by być preferowane przy selekcji na szybkość wzrostu. W pracy hodowlanej nad poprawą umięśnienia należy zwracać uwagę na zwierzęta z genotypem, ,ac”. Jednak w żadnej z przeprowadzonych analiz nie uzyskano 
istotnej zależności pomiędzy wartościami analizowanych cech a genotypem $C A S T$. Wykazano natomiast wysoko istotną zależność od roku badań. Uzyskane wyniki należy uznać jako wstępne. Badania należy więc kontynuować na większej grupie zwierząt zapewniającej odpowiednią liczebność poszczególnych genotypów. Odnotowane i opisane powyżej tendencje są również wskazówką ukierunkowującą przyszłe badania $\mathrm{w}$ tym zakresie. 